\title{
LEAN Manufacturing and Firm Performance in the Palm-Oil Industries in Delta State, Nigeria
}

Submitted 02/06/20, $1^{\text {st }}$ revision 14/07/20, $2^{\text {nd }}$ revision 24/08/2020, accepted 10/10/2020

\author{
Dr Emmanuel Mitaire Tarurhor ${ }^{1}$, Dr Ochuko B. Emudainohwo ${ }^{2}$
}

\begin{abstract}
:
Purpose: The paper aims to examine the effects of LEAN manufacturing practices on a firm's performance, considering lean culture as a moderating variable in Delta state's palm oil industries.

Design/Methodology/Approach: This study's sample was Palm oil industries located in Delta state and has been in existence for over ten years. Data were gathered through a survey of four hundred and thirty-three (433), and two hundred and four (204) were used to test the hypothesis. The study used the structural equation model to analyze the quantitative data generated from the four points Likert scale questionnaire.

Findings: We found that lean manufacturing proxied by empowerment, training, and development has a positive and statistically significant effect on a firm's performance in terms of product quality. Results proved that the lean culture had a negative impact on a firm's performance.

Practical Implications: Managers of organizations should consider the cultural background of the employees and where the organization is located to avert its negative impacts on the firm's performance.

Originality: The novelty of testing lean culture as a moderating variable on the relationship between lean manufacturing and firm performance.
\end{abstract}

Keywords: Empowerment, firm's performance, LEAN manufacturing, product quality, training and development.

JEL Code: L21, L27, N67.

Paper Type: Research study.

ISSN: 2241-4754, H index 10, Q3.

${ }^{1}$ Delta State University, Abraka, Nigeria, tarurhor@delsu.edu.ng;

${ }^{2}$ Delta State University, Abraka, Nigeria, emudainohwoob@delsu.edu.ng; 


\section{Introduction}

Nigeria manufacturing industries have witnessed a major growth due to the ban on imported goods by the federal government to boost local manufacturers. This policy has encouraged investors to invest in the manufacturing sector. For firms to survive in the industry, such manufacturing firms need to adopt strategies to reduce waste creation and increase products' quality. As part of the strategy for boosting locally manufactured goods, lean strategies are employed for enhancing the quality of products and services, but not primarily meant to eliminate waste in production. Basically, there is an interrelationship between waste reduction and quality improvement because quality improvement reduces the waste of products, which leads to business agility (Ofor-Nyarko, Boison, Asiedu, Agyapong and Ananoo, 2019). It had been established in the literature that waste could not be averted, but can be reduced by the application of lean manufacturing (Razi, Rakiman and Ahmed, 2015; Keitany and Riwo-Abudho, 2014; Tiwari and Tripathi, 2016; Iranmanesh, Zailani, Hyun, Ali and Kim, 2019).

Lean manufacturing primarily focuses on the reduction of waste in the production process to produce a high-quality product. Though, studies had shown that supply chain and operations management experts see managing waste as a major challenge for firms because failure to manage it effectively will increase operational cost and reduces product quality (Moori, Pescarmona and Kimura, 2013; Fullerton, Kennedy, and Widener, 2016; Bellisario and Pavlov, 2018; Ofor-Nyarko et al., 2019). In fact, Wheatley (2005) noted that "organization adopts lean manufacturing to maintain a competitive advantage in price and product, improve operational performance, to grow profit, customer demand for reduced prices and cycle times."

Implementation of lean practices came to the limelight due to the Japanese manufacturing firms' rapid growth. Tiwari and Tripathi (2016) noted that the Americans found out that the Japanese's success was associated with lean manufacturing (operations, production system, and management) rather than culture and ethics, which the world was thinking as the major determinant of their success in the 1970s. This novelty breakthrough had motivated researchers in both developed and developing countries to carry out studies on the importance of lean manufacturing on a firm's performance. Thus, studies had shown that the adoption of lean manufacturing by the organization could improve performance in areas of marketing (Ofor-Nyarko et al., 2019), environmental (Wiese, Luke, Heyus and Pisa, 2015; Caldera, Desha, and Dawes, 2017), operational (Minh, Zailani, Iranmanesh and Heidari, 2018; Ofor-Nyarko et al., 2019), social (Moreira, Alves and Sousa, 2010; Taubitz, 2010) and financial (Moyano-Fuentes, Sacistan-Diaz, 2012; Thanki, Govindan and Thakkar, 2016).

Though, many studies had been done to find out the best manufacturing practices as it relates to the manufacturing sector in different industries -electronics (Worley and Doolen, 2006), aerospace (Browning and Healh, 2009). ceramics (Bonavia and 
Marin,2006), automobile (Nordin, Deros and Wahab, 2010), Newspaper Printing (Othieno, 2016) and beverages ( Ofor-Nyarko et al., 2019). However, few existing empirical works in the palm oil industries relate to Delta State, Nigeria.

Previously in Nigeria, oil palm trees were growing skeletally and associated with communities. At present, it had grown into plantations and a major source of the crop for retail, industrial, and consumer markets (Hassan, Njeshu, Zhegwuni and Salisu, 2016). Palm oil processing is undertaken manually (climbing robes and cutlasses), small-scale (simple hand presses and stand-alone machines), and had gradually graduated to industrial mills (Hassan et al., 2016). Sahel (2015) demonstrated that since palm oil has numerous uses (cooking, processing, making soup, and so forth), its demand will increase as the Nigerian population is estimated to reach 450 million by 2050 .

However, for those palm trees that belong to the communities, Delta state's culture permits any farmer equal ownership rights to harvest them for production. If farmers can harvest such palm fruits at small or no cost and adopt lean manufacturing to avoid waste, the cost of production will be cheaper, which will enhance the firm's performance. This study intends to contribute and complement the few empirical works done on the palm oil industry in Delta state over the years. This study will also be a departure from most existing findings in this area by incorporating lean culture as a moderating variable between lean manufacturing and firm performance as it relates to the palm oil industries.

\section{Firm Performance Measurement}

Performance measurements are criteria developed by an organization to examine the performance and effectiveness of business operations. Previous studies had classified firm's performance into human resources effectively and managers perceptions ( $\mathrm{Yu}$ and Chiang, 2015), financial and non-financial (Drury, Braund, Osborne and Tayles, 1993; Gomes et al., 2004; Ishmail, 2007; and Kamilah and Shafi, 2016), qualitative and quantitative (Neely, Greogory and Platts, 1995). Researchers are at liberty to use any of the firm performance measurement tools depending on their study's nature. For instance, previous literature had shown that in a volatile market, the financial-based performance measurements would produce a spurious result because it cannot account for developmental changes in a technological and competitive environment (Drury et al., 1993; Ahmand and Zabri, 2016). Based on the above, this study will focus on the Non-financial Performance Measurements (NFPMS) in line with the studies of Ishmail (2007) and Ahmand and Zabri (2016), since the world is currently experiencing a very volatile market caused by the COVID-19 pandemic.

The NFPMS is the adequate measurement of firm performance suitable for this study. The following justify the choice of NFPMS: Firstly, NFPMS is more suitable for the manufacturing industry and volatile market (Abdel-Maksoud, Dugdale, and Luther, 2005). Secondly, Simons (1995) noted that NFPMS enhances effective 
communication among employees in the organization. Thirdly, Kaplan, and Norton (1992) stated that NFPMS helps managers identify organizational problems and proffer solutions. Thus, the following variables were used in the existing literature to measure NFPMS: market shares, productivity, efficiency, workforce development, product quality, on-time delivery, customer satisfaction, leadership, and employee satisfaction (Bagshaw, 2018; Yuliansyali and Razimi, 2015). In this regard, this study used product quality as a proxy for NFPMS. As defined by Kumar and Suresh (2008), the quality of the manufactured product is "the degree in which a product fulfills the customer's requirement. It is not absolute, but it judged or realized by comparing it with some standard."

\subsection{The LEAN Approach}

LEAN is interchangeably used as lean manufacturing, lean production, or lean enterprises by previous studies. Mwacharo (2013) argued that lean manufacturing had been applied in the industrialized world since the 1990s, with a primary purpose to produce quality products for consumers at lower prices. This is achievable by reducing waste associated with the production of such products. Billesbach (1994) found out that lean thinking increases profits in the textile industry. The researcher asserted that "the plant simultaneously achieved a 10 percent improvement in product quality and a 300 percent increase in employees' suggestions". In the same vein, Koumanakos (2008) noted that organizations that adopt lean manufacturing reported more profits than non-lean manufacturing companies, maintaining higher inventories.

Furthermore, Bodolay (2010) found out that managers who practice lean principles (lean managers) significantly increase productivity in the printing companies in California, USA, by saving time and money. At the same time, the non-managers spent more time in production and caused negative effects on productivity.

\subsection{LEAN Culture Pespective}

The term culture addresses how the employee feels, thinks and their perception towards organization they work. The above description is embedded in the definition of culture by Schein, 2010. He defines culture as "a pattern of shared basic assumptions that has been learnt whilst solving problems, that has worked well enough to be considered valid and therefore, to be taught to new members as the correct way to perceive, think, and feel in relation to those problems". The behaviour and the attitude of employee towards the organization is influenced by its culture and the organizational culture. Fellows and Liu (2013) asserted that there is a reverse relationship between culture and behaviour, that 'culture conditions behaviour and in turn, behaviour modifies culture'. Impliedly, culture can influence the behaviour of the employee towards the organization.

The success of any organization depends on the cordial interrelationship between structure, strategy and culture in pursuing a common goal (Bennett, Fadil and 
Greenwood, 1994). However, where culture is inconsistent with the organizational critical success factors, it may not improve performance (Byles, Aupperle and Arogyaswany, 1991). Thus, positive relationship exists between culture and performance (Peters and Waterman, 1982; Denison and Mishra, 1995). Thus, the study hypothesized that:

H1: LEAN culture has a significant and positive effect on a firm's performance.

H2: LEAN culture moderate significant and positive effect on lean manufacturing variables and firms' performance.

\subsection{LEAN Manufacturing Variables and Firm Performance}

Human resources practices played vital roles in lean manufacturing by creating a proper working environment and human capital development (Iranmanesh et al., 2019). It will be rare to find an organization that can achieve its goals without human resources. For an organization to be successful in implementing lean manufacturing, producing quality products, and having competitive advantages over competitors, it depends mostly on human resources (Blackburn and Rosen, 1993; Iranmanesh et al., 2019).

Iranmanesh et al. (2019) emphasize that trained and educated employees offer better ways to reduce waste and use materials effectively. However, non-trained and uneducated employees are more vulnerable to waste creation and mismanagement of the firm's materials. In this regard, staff should be trained to function effectively to combine other production factors to produce quality goods and services. As noted by Drucker (1977), "it is the responsibility of every manager to develop people, and also to direct, encourage and train their subordinates."

Russell, Terborg, and Powers (1985) found a positive and statistically significant relationship between training and organizational support on store performance in sixty -two retail stores. Furthermore, Bartels (1994), in her study on productivity gains, arises from the implementation of an employee training program, found a positive and significant relationship between human resources management practice and performance. The study uses a formal training program as a proxy for human resources management and labor productivity for firm performance.

Mullins (1996) noted that an organization requires talented and committed employees to reduce waste and produce quality goods at affordable prices. Employees are more productive if they are empowered to carry out their responsibilities (Pickard, 1993). Thus, empowerment gives the staff opportunity and freedom to use their acquired skills to make independent decisions concerning the organization's operations. Pickard (1993) found out that empowerment improved job satisfaction and changed the employee's attitude towards achieving better results in the study for harvester restaurant. Furthermore, Grontoos (2001) asserted that the proper implementation of employee empowerment positively impacts employee satisfaction, and it is also a 
major determinant of providing high-quality products or services. In the same vein, Kariuki and Kiambati (2017) established in their empirical study that employee empowerment had a positive and statistically significant impact on all organizational performance measurements. Impliedly, it can also impact quality products proxied for a firm's performance in this study. Based on the above, the following hypotheses are developed.

$H_{3}$ : Empowerment has a positive and significant effects on firm's performance.

$H_{4}$ : Training and development have a significant positive relationship on firm's performance.

\subsection{The Theoretical Lenses: Constraint Theory}

The study adopts the theory of constraints, which advocates that an organization can achieve its goals by reducing operating expenses and reducing its inventory to increase output. This theory was advocated by Goldratt in the 1980s, in his book titled 'The Goal.' The theory of constraints paradigm essential stated that every firm should have at least one constraint (Simatupang, Wright and Sridharan, 2004). Goldratt and Cox (1992) defined the theory of constraint as "a business attitude that strives for global objective, or goal, of a system by an understanding of underlying cause and effect. It takes a scientific approach to progress; it theorizes that every complex system, including manufacturing practices, consists of numerous linked activities, one which acts as a limitation upon the entire system."

This theory is most suitable for studies on manufacturing firms (Yang and Johansen, 2010). Yang and Johansen (2010) noted that the constraint theory is one of the theoretical views that studied the influence of traditional focus (manufacturing capabilities) with the market requirements. Consequently, the theory of constraints' principles aligns with the benefits enjoyed by an organization that applied lean manufacturing.

\subsection{Conceptual Framework}

Previous empirical studies had used market shares, productivity, efficiency, workforce development, product quality, on-time delivery, customer satisfaction, leadership, and employee satisfaction as measurements for non-financial performance (Bagshaw, 2018; Wonolo, 2018; Yuliansyah and Razim, 2015). Thus, lean manufacturing was also proxied by operational variables (Just-In-Time, Total Productive Maintenance and Automation) and human resources variables measured by empowerment, flexibility, and training and development (Tiwari and Tripati, 2016). Based on the above discussion, the proposed conceptual framework for this study investigates the effect of lean manufacturing (empowerment and training and development) on firm performance (product quality). Also, lean culture is introduced as a moderating variable. 
Figure 1. Proposed conceptual framework

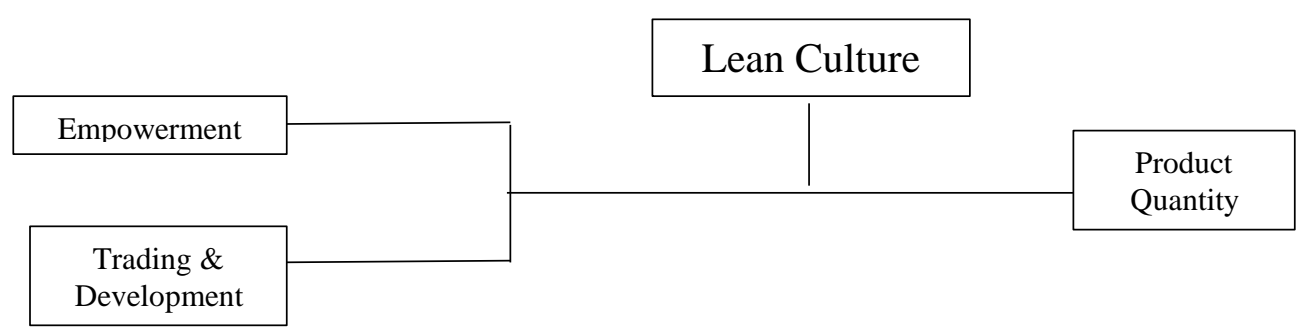

Source: Own study.

\section{Methodology}

In line with Nyangahu and Bula (2015), the positivist's method will be adopted in this study because it has the ability to test for hypotheses whose data are derived using measurable variables from the population. The study adopts a survey research design, which is most suitable for this work since the researcher has the privilege to collect useful data directly from the respondents (Cohen, Manim and Morrison, 2011). Data used for the analysis were generated from the responses received from the structured questionnaires. Each measurable variable's instrumentation was chosen from previous related empirical studies (Iranmanesh et al., 2019; Tiwari and Tripati, 2016; OforNyarko et al., 2019).

A population of four hundred and thirty-three (433) was selected from oil palm processing factories in Delta state, which have been in operations for over ten years. The study uses a proportionate sampling technique to ascertain the numbers of questionnaires distributed to three senatorial districts in Delta state. The sample size of 208 was derived using the Taro-Yamane sampling technique. Based on the sample size, 208 copies of questionnaires were administered, and 204 were found useful from the received copies. Existing literature suggests that studies involving mediating or moderating variables, the structural equation model (SEM), are the most suitable statistical tools for such analysis (Sun and Chiou, 2014; Tarurhor, 2017a; Tarurhor, 2017b; Civelek, 2018). In line with the above, the structural equation model (SEM) was used to capture lean culture's effect on the relationship between lean manufacturing and non-financial firms' performance in Delta state. Thus, STATA 13.0 was used to run the SEM analysis.

\subsection{Model Specification}

The relationship between proxy of NFPMS and lean manufacturing including the moderating variable of lean culture will be established using SEM.

$$
\begin{aligned}
& \mathrm{PQTY}=\beta_{0}+\beta_{1} \text { EMPT }+\beta_{2} \mathrm{TDT}+\varepsilon-\beta_{1}-\beta_{-}- \\
& \mathrm{PQTY}=\beta_{0}+\beta_{1} \mathrm{EMPT}+\beta_{2} \mathrm{TDT}+\beta_{3} \mathrm{LC}+\varepsilon \quad-\quad- \\
& \mathrm{LC}=\beta_{0}+\beta_{1} \mathrm{EMPT}+\beta_{2} \mathrm{TDT}+\varepsilon_{-} \quad-\quad-\quad-
\end{aligned}
$$


Where:

PQTY = Product quality $;$ EMPT $=$ Empowerment TDT $=$ Training and development $\mathrm{LC}=$ Lean culture .

\section{Results and Discussion}

In Table 1, the study's descriptive statistics report an observation of 204, which justified that the four (4) nonuseful questionnaires were excluded from the sampled used for analysis. Furthermore, the records also showed that most palm oil firms in Delta state consider their staff's welfare and give them opportunities to develop themselves, reporting the highest mean of 3.1804 on empowerment. Thus, empowerment is the most dominant factor that influences performance (product quality). The effect of lean performance practice on performance is normally distributed, as shown with high standard deviation. Therefore, the standard deviation result ascertained that the selected firms had a high performance (Zolait et al., 2010).

Table 1. Descriptive Statistics

\begin{tabular}{|l|l|l|l|l|l|}
\hline Variable & Obs & Mean & Std. Dev. & Min & Max \\
\hline Pqty & 204 & 2.6618 & 1.0126 & 1.5 & 4.0000 \\
\hline empt & 204 & 3.1804 & 0.5053 & 2.2 & 4.6000 \\
\hline Tdt & 204 & 2.5098 & 0.5922 & 1.6667 & 4.0000 \\
\hline Lc & 204 & 2.4739 & 0.6796 & 1.6667 & 4.6667 \\
\hline
\end{tabular}

Source: Authors computation, 2020.

Furthermore, the correlation matrix in Table 2, shows that firm's performance proxied by product quality has strong relationship with training and development at $83 \%$. Though, its relationship with empowerment is $67 \%$ and lean culture $16 \%$ indicating a moderate relationship.

Table 2. Correlation matrix

\begin{tabular}{l|llll}
\hline & Pqty & Empt & $t d t$ & $l c$ \\
\hline Pqty & 1.0000 & & & \\
Empt & 0.6676 & 1.0000 & & \\
Tdt & 0.8338 & 0.5888 & 1.0000 & 1.0000 \\
Lc & 0.1649 & 0.4566 & 0.1203 &
\end{tabular}

Source: Authors computation, 2020.

In line with Dimitros and Hall (2015), the results did not show multicollinearity evidence because none of the values in the correlation matrix is more than 0.900 thresholds. Furthermore, the multicollinearity test (table not included) shows that the highest VIF is 1.99 , which is far below the thumb rule of 7 . Additionally, the study performed Cronbach Alpha to examine the internal consistency of the data. The result revealed a scale reliability coefficient of 0.7477 , which lies between the acceptable range of 0.7 and 0.9 (Tavakol and Dennick, 2011), and it suggests that the data can be relied upon for this study. 
Furthermore, Kline (2005) emphasized the need to ascertain whether an SEM model is suitable for a particular study. He suggested that four indices most be considered as a benchmark for accepting the fitness of the SEM model. They are the Comparative Fit Index (CFI), Chi-square, Root Mean Square Error of Approximation (RMSEA), and SRMR. The study result showed that CFI $1.000(\geq 0.90)$, Chi-square $24.108(\geq$ 0.95), RMSEA $(\leq 0.08)$, and SRMR $(\leq 0.08)$. Based on the above, the SEM model is suitable for this study.

Additionally, the result of the SEM, as reported in Table 3 and Figure 2, indicate that firms' performance measured by product quality has a positive and statistically significant relationship with empowerment (0.6) at a $1 \%$ level of significance. This finding is consistent with the works of Kariuki and Kiambati (2017). In the same vein, the relationship between training and development; and product quality also reported a positive and statistically significant relationship at a $1 \%$ level of significance. These reports support the studies of Russell et al. (1985) and Bartel (1994). However, the study established a negative and non-statistical significance relationship between product quality and lean culture, as shown in table 3 . This result is at variance with Peters and Waterman (1982) works and Denison and Mishra (1995). However, it supports the works of Byles et al. (1991).

Table 3. SEM results

\begin{tabular}{|c|l|l|}
\hline & Model 2 & Model 3 \\
\hline Coefficients- lc & -0.0781 & \\
\hline Empt & $0.6038^{*}$ & $0.7939^{*}$ \\
\hline Tdt & $1.1331^{*}$ & $-0.2608^{*}$ \\
\hline
\end{tabular}

Note: $* P<0.01$

Source: Authors computation, 2020.

Figure 2. SEM Diagram

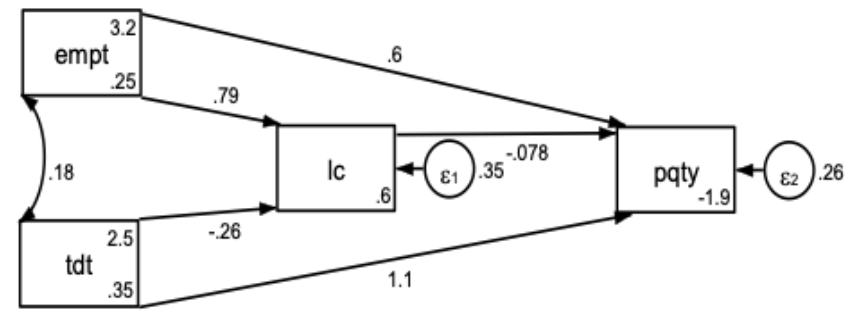

Source: Authors computation, 2020.

Thus, the relationship between lean culture and empowerment is positive (0.79), whereas its relationship with training and development indicates a negative relationship (-0.26) at $1 \%$ level of significance respectively. 


\section{Conclusion}

This study has been able to establish the relationship between lean manufacturing practice and firm's performance taking into consideration lean culture as a moderating variable in the Palm oil industries in Delta state. The study also noted that empowerment, training and development have positive and statistically significant effects on firm's performance with regards to product quality. However, the lean culture had a negative relationship with firms' performance, training and development; though its relationship with empowerment is positive and significant.

Finally, the study observed that lean manufacturing can enhance firm's performance, while lean culture had a negative impact on product quality of the products. Similarly, managers of organizations should as a matter of imperative consider the culture cultural background of the employees and people where the organization is located; to avert its negative impacts on firm's performance.

\section{References:}

Abdel-Maksoud, A., Dugdale, D., Luther, R. 2005. Non-Financial Performance Measurement in Manufacturing Companies. The British Accounting Review, 37, 261297.

Ahmad, K., Zabri, S.M. 2016. The Application of Non-Financial Performance Measurement in Malaysian Manufacturing Firms. Procedia Economics and Finance, 35, 476-484.

Bagshaw, K.B. 2018. Lean Application and Efficiency of Manufacturing Firms: An Empirical Study of Manufacturing Firms in Rivers State, Nigeria. International Journal of Management Excellence, 11(2), 1553-1558

Bartels, A.P. 1994. Productivity Gains from the Implementation of Employee Training Programs: Industrial Relations. A Journal of Economy and Society, 33(4), 411-425.

Bellisario, A., Pavlov, A. 2018. Performance Management Practices in Lean Manufacturing Organizations: A Systematic Review of Research Evidence. Production Planning and Control, 11(1), 1-21.

Bennett, R.H., Fadil, P.A., Greenwood, R.T. 1994. Cultural Alignment in Response to Strategic Organizational Change: New Considerations for a Change Framework. Journal of Managerial Issues, 6, 474-490.

Billesbach, T.J. 1994. Applying Lean Production Principles to a Process Facility. Production and Inventory Management Journal, Third Quarter, 40-44.

Blackburn, R., Rosen, B. 1993. Total Quality and Human Resources Management: Lessons Learned from Baldrige Award-Winning Companies. Academic of Management Perspective, 7, 49-66.

Bodolay, J. 2010. Impact of Lean Practices on Printing Companies. Retrieved from htt://digitalcommons.calpoly.edu/cgi/view content.cgi?article=1027\&context=gresp.

Bonavia, T., Marin, J.A. 2006. An Empirical Study of Lean Production in the Ceramic Tile Industry in Spain. International Journal of Operation Production Management, 26, 505531.

Browning, T.R., Heath, R.D. 2009. Reconceptualizing the Effects of Lean on Production Costs with Evidence from the F-22 Program. Journal Operational Management, 27, 2344.

Byles, M.C., Aupperle, E.K., Arogyaswamy, B. 1991. Organizational Performance. Journal 
of Managerial 3, 512-527.

Caldera, H.T.S., Desha, C., Dawes, L. 2017. Exploring the Role of Lean Thinking in Sustainable Business Practice: A Systematic Literature Review. Journal Cleaner Production, 167, 1546-1565.

Civelek, M.E. 2018. Essentials of Structural Equation Modeling. Zea Books Lincon, Nebraska.

Cohen, L., Manion, L., Morrison, K. 2011. Research Methods in Education ( $7^{\text {th }}$ Edition). London, Routledge.

Denison, D.R., Mishra, A.K. 1995. Towards a Theory of Organizational Culture and Effectiveness. Organization Science, 6, 204-233.

Drucker, P.F. 1977. People and Performance. Heinemann.

Drury, C., Braund, S., Osborne, P., Tayles, M. 1993. A Survey of Management Accounting Practices in UK Manufacturing Companies. Chartered Association of Certified Accountants.

Fellows, R., Liu., M.M.A. 2013. Use and Misuse of the Concept of Culture. Construction Management and Economics, 31, 401-422.

Fullerton, R.R., Kennedy, F.A., Widener, S.K. 2016. Lean Manufacturing and Firm Performance: The Incremental Contribution of Lean Management Accounting Practices. Journal of Operations Management, 32, 414-428.

Goldratt, E.M., Cox, J. 1992. The Goal: A Process of Ongoing Improvement. Second Revised Edition. North River Press Publishing Corporation, Great Barrington, M.A.

Gomes, C.F., Yasin, M.M., Lisboa, J.V. 2004. An Examination of Manufacturing Organizations' Performance Evaluation, Analysis, Implications and a Framework for Future Research. International Journal of Operations and Production Management, 24(5), 488-513.

Hassan, M.A., Njeshu, G., Raji., Zhengwuvi, L., Salisu, J. 2016. Small-Scale Palm Oil Processing in West and Central Africa: Development and challenges. Journal of Applied Sciences and Environment Sustainability, 2(5), 102-114.

Iranmanesh M., Zailani, S., Hyun., S.S., Ali., M.H., Kim, K. 2019. Impact of Lean Manufacturing Practives of Firms' Sustainable Performance: Lean Culture as a Moderator. Sustainability, 11(112), 1-20.

Ismail, N.A., King, M. 2007. Factors Influencing the Alignment of Accounting Information Systems in Small and Medium Sized Malaysian Manufacturing Firms. Journal of Information Systems and Small Business, 1(1/2), 1-20.

Kamilah, A., Shafi, Z.M. 2015. The Application of non-Financial Performance Measurement in Malaysian Manufacturing Firms. Procedia Economics and Finance, 35(2016), 476484.

Kaplan, R.S., Norton, D.P. 1992. The Balanced Scorecard- Measures that Drive Performance. Harvard Business Review, 70 (1), 71-79.

Kariuku, A., Kiambati, K. 2017. Empowerment, Organizational, Commitment, Organization Citizenship Behavior and Firm Performance. Management Studies, 5(4), 290-300.

Keitany, R., Riwo-Abudho, M. 2014. Effects of Lean Production on Organizational Performance: A Case Study of Flour Producing Company in Kenya. European Journal of Logistics Purchasing and Supply Chain Management, 2(2), 1-14.

Kline, R.B. 2005. Principles and Practice of Structural Equation Modeling ( $3^{\text {rd }}$ Ed.). New York, Guilford

Koumanakos, D.P. 2008. The Effect of Inventory Management on Firm Performance. International Journal of Productivity and Performance Management, 57(5), 355-369.

Minh, K.S., Zailani, S., Iranmanesh, M., Heidari, S. 2018. Do Lean Manufacturing Practices 
have Negative Impact on Job Satisfaction? International Journal of Lean Six Sigma.

Moori, R.G., Pescarmona, A., Kimura, H. 2013. Lean Manufacturing and Business

Performance in Brazilian. Journal of Operations and Supply Chain Management, 6(1),

91-108. DOI: 10.12660/joscmv6n1p91-105.

Moreira, F., Alves, A.C., Sousa, R.M. 2010. Towards Eco-Efficient Lean Production

Systems. In Balanced Automation Systems for Future Manufacturing Networks.

Springer, Berlin, Germany, 100-108.

Moyano-Fuentes, J., Sacristán-Díaz, M. 2012. Learning on Lean: A Review of Thinking and

Research. International Journal of Operation and Production Management, 32, 551 582.

Mullins, L.J. 1996. Management and Organizational Behaviour, Fourth Edition. Pitman Publishing.

Mwacharo, F.K. 2013. Challenges of Lean Management: Investigating the Challenges and Developing a Recommendation for Implementing Lean Management Techniques. A Bachelor's Thesis Submitted to the Department of Supply Chain Management. Hamk University of Applied Sciences.

Neely, A.D., Gregory, M.J., Platts, K. 1995. Performance Measurement System Design: A

Literature Review and Research Agenda. International Journal of Operations and

Production Management, 15(4), 80-116.

Nordin, N., Deros, B.M., Wahab, D.A. 2010. A Survey on Lean Manufacturing

Implementation in Malaysian Automotive Industry. International Journal of Innovation and Management Technology, 1, 374.

Nyangalu, K.P., Bula, H.O. 2015. Relationship Between Work Stress and Performance of Employees: A Case Study of Transit Hotel in Nairobi City County. Archives of Business Research, 3(6), 22-37.

Ofor-Nyarko, E., Boison, D.K., Asiedu, E., Agyapong, N.K., Anamoo, R.A.Y. 2019. The Effect of Lean Operations in Manufacturing on Firm Performance: The Case of Manufacturing Firms in Accra. International Journal of Engineering Research and Reviews, 7(2), 1-7.

Othieno, K.J. 2016. Lean Practices and Operational Performance of Nation Newspaper Printing Division, Kenya. A Masters Thesis in Department of Business Administration, Submitted to School of Business, University of Nairobi.

Peters, T.J., Waterman, H.R. 1982. In Search of Excellence, Lessons from American's BestRun Companies. New York, Harper and RON.

Pickard, J. 1993. The Real Meaning of Empowerment. Personnel Management, 35(11), 28 33.

Rasi, R.Z.R.M., Rakiman, U.S., Ahmad, F.B. 2015. Relationship between Lean Production and Operational Performance in the Manufacturing Industry. Materials Science and Engineering, 83, 1-11.

Russell, J.S., Terborg, J.R., Powers, M.L. 1985. Organizational Performance and Organizational Level Training and Support. Personnel Psychology, 38(4), 849-863.

SAHEL Newsletter. 2015. Unlocking the Palm Oil Potential in West Africa. Retrieved from https://sahelcp.com/wp-content/uploads/2016/12/Sahel-Newsletter-Volume-10.

Schein, E.H. Organizational Culture; American Psychological Association: Washington, DC, USA, 2010, 45, ISBN 1557980926.

Simatupang, T.M., Wright, A.C., Sridharan, R. 2004. Applying the Theory of Constraints to supply Chain Collaboration. Supply Chain Management. An International Journal, 9(6), 234-276.

Simons, R. 1995. Levers of control: How Managers use Innovative Control Systems to Drive 
Strategic Renewal. Boston, Harvard Business School Press.

Sun, K., Chiou, H. 2014. Aviation Ground Crews: Occupational Stresses and Work Performance. African Journal of Business Management, 5(7), 2865-2873.

Tarurhor, M.E. 2017a. The Moderating Effect of Firm Size on Board Directors- Firm's Performance Relationship: Evidence from the Financial Sector. AAU Journal of Management Sciences, 8(1-2), 85-96.

Tarurhor, M.E. 2017b. Work Stress and Employees' Performance amongst Staff of Delta State University, Abraka: The Moderating Role of Career Development. Ilorin Journal of Management Sciences, 4(1), 1-12.

Tavakol, M., Dennick, R. 2011. Making Sense of Cronbach's Alpha. International Journal of Medical Education, 2, 53-55. DOI: 10.5116/ijme.4dfb.8dfd.

Thanki, S., Govindan, K., Thakkar, J. 2016. An Investigation on Lean-Green Implementation Practices in Indian SMEs Using Analytical Hierarchy Process (AHP) Approach. Journal of Cleaner Prod., 135, 284-298.

Tiwari, S., Tripathi, N. 2016. Lean Manufacturing Practices and Firm's Performance Measurement: A Review Paper Lean Manufacturing Practice and Firm's Performance Measurement. International Journal of Supply Chain Management Systems, 1-12.

Wheatly, M. 2005. Think Lean for the Long Term. In: Manufacturing Business Technology, June 2005, 36-38. Retrieved from https://www.researchgate.net/publication/291478851Think_lean_for_the_long_term/cit ation/download.

Wiese, A., Luke, R., Heyns, G.J., Pisa, N.M. 2015. The Integration of Lean, Green and best Practice Business Principles. Journal of Transport and Supply Chain Management, 9, 1-10.

Wonolo, A. 2018. Workforce Development. Definition and Strategies. Retrieved from https://www.wonolo.com/blog/what-is-workforce-development.

Worley, J.M., Doolen, T.L. 2006. The Role of Communication and Management Support in a Lean Manufacturing Implementation. Management Decisions, 44, 228-245.

Yang, C., Johansen, J. 2010. Open Manufacturing: Impacts of Resource-Based View and Servitisation. In sixteenth International Working Seminar on Production Economics, Innsbruck.

Yuliansyah, Y., Razimi, M.S.A. 2015. Non-Financial Performance Measures and Managerial Performance: The Mediation Role of Innovation in an Indonesian Stock ExchangeListed Organization. Problems and Perspectives in Management, 13(4), 135-147.

Zolait, A., Ibrahim, A.R., Chandran, V.G.R., Sundram, V.P.K. 2010. Supply Chain Integration: An Empirical Study on Manufacturing Industry in Malaysia. Journal of Systems and Information Technology, 12(3), 210-221. 